recognize mutual benefits from interaction---largely as a result of legislation and policies which encourage cooperation. Native involvement officers now facilitate coordination in the Yukon and Alaska. Park agency native employment programmes are proceeding in all three 'hinterlands', while native people can own land on which national parks are established in Alaska and the Australian Northern Territory. Only in Australia are native people known to be directly involved in upperlevel national park management. Potential limitations on native subsistence and associated use of national parks range from moderate to severe, and are only defined clearly in Alaska. Lack of definition leads to confusion in deciding upon native use, while exceedingly precise definition precludes flexibility at the park level.

A number of aids to a more mutually satisfactory interaction can be identified. One is motivation, or recognition by both parties that there are advantages to consultation and cooperation. Another, not yet achieved in the Yukon, is a land-claims settlement, stating the legislated rights of native peoples in the 'hinterlands' and giving them a land-holding and bargaining status which is comparable with that of government agencies. A third aid is comprehensive systematic and regional planning efforts involving opportunities for informed input from all affected parties. Such planning would provide a forum for consideration of a variety of interests, including national parks and native peoples. Finally, satisfactory interaction on the park site could be assisted by clear yet flexible means of deciding upon acceptable native use of parkland, the conservation of wildlife, and associated economic and cultural factors.

\section{REFERENCES}

ARMSTRONG, G. (1977). A comparison of Australian and Canadian approaches to national park planning. Pp. 220-8 in Leisure and Recreation in Australia (Ed. D. Mercer). Sorrett Publishing, Malvern, Australia: $264 \mathrm{pp}$.

COUNCIL FOR YUKON INDIANS (undated). Together Today For Our Children Tomorrow. Carters Publishing Company, Brampton, Ontario: $140 \mathrm{pp}$.

DEPARTMENT OF ABORIGINAL AFFAIRS (1979). Background Notes: Aboriginal Land Rights (Northern Territory)
Act 1976. No. 1 (Revised). Department of Indian and Northern Affairs, Canberra, Australia: 8 pp.

GARDNER, J. E. (1979). National Parks and Native People in Northern Canada. M.A. thesis, Department of Geography, University of Waterloo, Waterloo, Ontario: viii $+223 \mathrm{pp}$., illustr.

GARDNER, J. E. \& NELSON, J. G. (1980). Comparing national park and related reserve policy in hinterland areas: Alaska, Northern Canada, and Northern Australia. Environmental Conservation, 7(1), pp. 43-50, 3 maps.

HUNT, C. D. (1978). Approaches to native land settlements and implications for northern land-use and resource management policies. Pp. 5-41 in Northern Transitions, Vol. 2 (Ed. R. T. Keith \& J. B. Wright). Canadian Arctic Resources Committee, Ottawa, Ontario: xiv +470 pp., illustr.

KRESGE, D. T., MOREHOUSE, T. A. \& ROGERS, G. W. (1977). Issues in Alaska Development. University of Washington Press, Seattle, Washington: 223 pp., illustr.

PARKS CANADA (1978). Parks Canada Draft Policy. Parks Canada Department of Indian and Northern Affairs, Ottawa, Ontario: $118 \mathrm{pp}$.

PARKS CANADA (1979). Parks Canada Policy. Parks Canada Department of Indian and Northern Affairs, Ottawa, Ontario: $79 \mathrm{pp}$.

REDPATH, D. K. (1979). Land Use Programs in Canada: Yukon Territory. Minister of Supply and Services Canada, Hull, Quebec: 303 pp., illustr.

THEBERGE, J. B. (1978). Kluane National Park. Pp. 151-89 in Northern Transitions, Vol. 1 (Ed. E. B. Peterson \& J. B. Wright). Canadian Arctic Resources Committee, Ottawa, Ontario: $x v+320$ pp., illustr.

THEBERGE, J. B., NELSON, J. G. \& FENGE, T. (Ed.) (1980). Environmentally Significant Areas of the Yukon Territory. Canadian Arctic Resources Committee, Ottawa: xiv + 134 pp., illustr.

\section{LEGISLATION CITED}

\section{Australia}

Aboriginal Land Rights (Northern Territory) Act of 1976. National Parks and Wildlife Conservation Act of 1975.

Territory Parks and Wildlife Ordinance of 1976.

Canada

National Parks Act of 1930, Amended 1974.

United States

Alaska Native Claims Settlement Act of 1971.

Alaska National Interest Lands Conservation Act of 1978, passed by House of Representatives (HR. 39) but not by Senate.

\title{
Belgian Actions to Stop Illegal Trade in Endangered Wild Biota
}

One of Europe's remaining major conduits of trade in rare animals and plants was closed from this summer when the Belgian parliament unanimously ratified CITES (also known as the Washington Convention), the international treaty which regulates trade in endangered biota.

An estimated US\$ 30 millions worth of endangered animals and animal products alone passed through Belgium in 1980, when more than 50 tons of ivory were flown in openly. This will have represented at least 4,000 African Elephants (Loxodonta africana), and considerably more ivory entered Brussels 'in transit' without being recorded. The extensive Belgian trade in internationally protected Chimpanzees (Anthropopithecus troglodites), Cheetahs (Acinonyx jubata), and various parrots, as well as rare furs, will also be brought under control by this ratification of CITES (Convention on International Trade in Endangered Species of Wild Fauna and Flora), which takes effect when the instrument is deposited in Berne, Switzerland.

Belgium's decision clears the way for immediate ratification of CITES by both Luxembourg and the Netherlands, which endorsed CITES in 1975 and 1980 , respectively, but which were unable, under provisions of the Benelux Customs Union, to ratify formally the treaty until Belgium also agreed.

'The Belgian decision also spurs the entire European Community to enforce CITES', noted WWF International Director-General Charles de Haes. 'Greece and Ireland are expected to ratify shortly, and we are hopeful that the remaining European countries which have not yet 
joined CITES will also do so this year-Austria and Spain in particular.' Other major animal trading nations yet to ratify the Convention include Colombia, Mexico, Singapore, Sudan, and Thailand.

HRH The Duke of Edinburgh, WWF International President, noted in a congratulatory telegram to the Belgian Prime Minister: 'Since stopping trade in endangered species is one of the most urgent requirements to achieve the conservation of wildlife world-wide, the news that the Belgian Parliament has ratified the Washington Convention is ... warmly welcomed by World Wildlife Fund International and all its supporters.'

WWF Belgium and other conservation organizations have worked for years to draw public attention to illegal trading activities in their country. One dramatic exposé resulted in 1980 when a photojournalist from the German magazine Stern, working in collaboration with WWF, toured the premises of an animal importer and recorded a tragic scene: caged Demoiselle Cranes (Anthropoides virgo), parrots, Leopards (Panthera pardus), and other animals which are protected under CITES, were awaiting sale or shipment_-often in deplorable condition. Enlisted as 'junior detectives', members of the Belgian WWF youth club reconnoitred the streets, recording license numbers of cars parked near the trader's shop. The numbers were later reported to guards at the German border and double checked against vehicles leaving Belgium. This resulted in the confiscation of more than 20 illegally-obtained Chimpanzees and extensive press-coverage.

The ivory trade has flowed through Belgium with the intricacy of an international commodity exchange. Ivory from Zaire (a CITES member) is flown from Burundi (a country with no Elephants, and which is not a CITES member) into Belgium on Sabena Airlines and other carriers. Sabena is among the carriers which signed an agreement, developed by WWF and endorsed by most IATA airlines, not to carry endangered species as cargo. The low average weight of the tusks indicates that many young elephants are being slaughtered, owing to the scarcity of big 'tuskers' and the indiscriminate methods of poachers, who kill all Elephants regardless of size. The ivory is then stockpiled as an investment or shipped to dealers in the Far East-often with dubious export documents that camouflage the true origin of the shipment.

The Belgian decision came shortly after the entry into force, on June 6 , of the revised CITES protection lists that were recently adopted by all member states at a conference in New Delhi, India. The new lists now contain more than 2,000 species of endangered wild animals (ranging from whales to parrots and even butterflies) and several thousand species of wild plants (including certain orchids and cacti).

Because implementation of CITES is so important, WWF Belgium is prepared to sponsor education programmes for customs officials to help them in their tasks of identifying endangered animals and animal products.

\section{Paul S. Wachtel, Public Affairs Coordinator WWF International Avenue du Mont-Blanc 1196 Gland, Switzerland.}

\section{China's Green Frenzy}

In China, March 12th is the Day of the Tree, when each person, from the high official to the schoolchild, is supposed to plant a tree-or, as the Chinese say, 'replant' it. Thus the whole country is seized annually with a kind of 'green frenzy', as if it were dreaming of China's golden age when trees were everywhere to be seen. A western expert estimated in 1980 that the tree-planting campaign in that year was so effective that from 12 to 14 thousand million trees were set in the ground. This year, just before the Day of the Tree, the Government announced that China had $12.7 \%$ of its surface area under woodland. The aim is to reach $20 \%$ by the year 2000 . The Chinese party Central Committee called on all cadres, students, workers, and soldiers, to plant trees once a year; but in the countryside, the peasants are employed to plant trees all the year around.

The Chinese talk of constructing a second 'Great Wall' of trees. At least 7,000 kilometres ( 4,400 miles) long, it is expected to run roughly parallel to the old Great Wall, and prevent the north of the country from becoming more and more desertic. It should also raise the standard of living through better land management, and help in the fight against pollution. In 1979 the Central Committee published a forest code, one objective of which is to prevent the towns from becoming hemmed in by asphalt and concrete. Peking, for instance, boasts 3-4 square metres of greenery per inhabitant, and the famous Tien an Men (Heavenly Peace) Square is now surrounded by pine trees. Nanking has 3 square metres of greenery per inhabitant, and last year finished planting trees along its 40 main avenues.
Planners in China are required to surround suburban towns with a curtain of trees, to separate them from their industrial zones. Chinsaw, a dormitory town for petrochemical workers in Shanghai, is completely screened from the factories by a green belt which varies in thickness in different parts from a few metres to several kilometres. The Chinese plant different trees to solve different problems. Thus plane trees (Platanus spp.) are commonly chosen because of their very dense foliage, being thought to be best to bring shade to city boulevards. Along major roads and railways, eucalypts (Eucalyptus spp.) are often chosen because they tend to be bushier lower down than other trees, and so act as windbreaks. For regions where there is intense industrial air pollution, Mrs Kong Guo Hui, a research worker from the Botanical Gardens in Canton, has built up a shortlist of pollution-resistant trees. Her research has two objectives, the first being to find plants that can serve as indicators of danger. Thus when a piece of vegetation that is normally resistant to smoke and fumes starts to wilt, for example, it can be a warning that pollution has reached a hazardous level. Secondly, Mrs Kong has tried to calculate how much pollution each plant 'eats', for it seems that forests may offer real prospects of a new 'soft' method of fighting some kinds of pollution.

Jacques Poncin
c/o Earthscan
10 Percy Street
London WIP ODR
England, UK.

Jacques Poncin 10 Percy Street England, $U K$. 